\title{
The status quo of enterprise architecture implementation in South African financial services companies
}

\author{
M.C. Matthee \\ Department of Informatics, University of Pretoria, \\ Pretoria 0001, Republic of South Africa \\ Machdel matthee@up.ac.za \\ P.K.J. Tobin* \\ Gordon Institute of Business Science, University of Pretoria, \\ Pretoria 0001, Republic of South Africa \\ tobinp@gibs.co.za \\ P. van der Merwe \\ Department of Informatics, University of Pretoria, \\ Pretoria 0001, Republic of South Africa \\ paul.vandermerwe@realirm.co.za
}

Received October 2006

\begin{abstract}
This article presents the findings of research that was conducted amongst Enterprise Architecture (EA) practitioners in the South African financial services sector. Due to the duration and cost implications of EA projects, factors that contribute to the success and failure of EA initiatives need to be investigated and identified. The research was largely based on a similar international study that was conducted by Schekkerman (2004b). A number of aspects of EA were investigated, including the place of EA in organisational and strategic governance, the EA architects, practices and processes, as well as the measurement of EA initiatives. Key findings from the study were that South African companies surveyed demonstrated lower levels of maturity in their approaches to the management of EA practices and processes; also identified were significant differences in the approach in South African respondents compared to international studies with respect to ownership of EA initiatives and the types of EA frameworks and modelling techniques in use.
\end{abstract}

*To whom all correspondence should be addressed.

\section{Introduction}

This research had a focus on companies listed on the Johannesburg Stock Exchange (JSE) in the financial services sector in South Africa (SA) and their use and involvement in Enterprise Architecture (EA). The reason for this focus on the financial services sector was due to the significant role played by organisations in that sector in the South African economy and the relative importance in terms of the use of information systems and technology in those organisations. This article explains the nature and development of the interest in EA and then reports on the research conducted and the findings of that research.

\section{What is enterprise architecture?}

The origins of the recognition of the role and importance of an Enterprise Architecture as a contributor to organisational success has been traced back to the landmark publication by Zachman (1987) in which he first outlined his 'A framework for information systems architecture' (Hagan, 2004; Schekkerman, 2004a; Tang, Han \& Chen, 2004). The Zachman framework for information systems was later extended (Sowa \& Zachman, 1992) and formally renamed A
Framework for Enterprise Architecture in 2000 (Bernus, Nemes \& Schmidt, 2003).

Zachman's (1996a:5) definition of enterprise architecture was: 'Descriptive representations (i.e. models) that are relevant for describing an enterprise such that it can be produced to management's requirements (quality) and maintained over the period of its useful life (change).' Zachman (1996a) identified five different perspectives: Planner, Owner, Designer, Builder, and Sub-Contractor. He also identified six characteristics, also called abstractions: What, How, Where, Who, When, and Why (Zachman, 1996a). Zachman described his framework as 'simple...comprehensive....a language...a planning tool...a problem-solving tool...neutral...the framework for enterprise architecture is not 'the answer'. It is a tool.... a tool for thinking. If it is employed with understanding, it should be of great benefit to technical and non-technical management alike in dealing with the complexities and dynamics of the information age enterprise' (Zachman, 1996b:4).

Following Zachman (1987), Spewak was among the first to use the term Enterprise Architecture in his seminal book 
(Spewak, 1992), taking the approach of using EA to present a conceptual map of an organisation from many perspectives - from business, applications, information and technological points of view (Spewak, 1992). Spewak's emphasis was on EA planning (which in his view had seven components, at four levels), thus creating the top two layers of the Zachman information systems framework. EA Planning (EAP) became: 'The process of defining architectures for the use of information in support of the business and a plan for implementing those architectures...EAP is a how to approach for creating the top two rows of the Zachman framework, Planner and Owner,' (CIOC, 1999:20). The design of systems, which begins in the third row of Zachman's framework, is outside the scope of EAP (IEAC, 2006b).

An EA may also be defined as a series of architectural models. In the early days, these models were only defined at the level of an Information Technology (IT) architecture, as was the case for Zachman (1987). 'An IT architecture comprises five interrelated architectural models. Each of these represents a different view or perspective of the way IT will provide the desired business results. These architectural models are the business architecture; the system architecture; the information architecture; the application architecture; and the technology architecture,' (Tapscott \& Caston, 1993:238). This five-model view was later refined by other authors who defined only four architectural layers. Van der Klashorst (2001) stated that 'enterprise architecture... typically consists of current and future state models of four key components, namely enterprise business architecture, enterprise information architecture, enterprise application architecture and enterprise-wide technical architecture' a view supported by other authors (Du Preez, 2003; EWITA, 2002; Koch, 2005; Pelz-Sharpe \& Harris-Jones, 2005). A view that is aligned to the Zachman Framework is that EA is 'the who, what, why, when, where and how of the business at every level from high-level corporate goals to the code of low-level programs that implement business processes used to achieve those goals,' (Harrison \& Varveris, 2004).

Hagan (2004:12) offered a definition of EA from a legal perspective noting that the E-Government Act of 2002 (Public Law (PL) 107-347) states that Enterprise Architecture means: 'A strategic information asset base, which defines the mission; the information necessary to perform the mission; the technologies necessary to perform the mission; and the transitional processes for implementing new technologies in response to changing needs; and includes: a baseline architecture; a target architecture; and a sequencing plan.'

Even accepting these perspectives, the definition chosen for the current study comes from Schekkerman (2004a). The reason for this choice was the extent to which the current study was based on the findings of Schekkerman (2004a, 2004b) and the possibility of extending those studies as a key element of this current research.

'Enterprise Architecture is a complete expression of the enterprise; a master plan which acts as a collaboration force between aspects of business planning such as goals, visions, strategies and governance principles; aspects of business operations such as business terms, organisation structures, processes and data; aspects of automation such as information systems and databases; and the enabling technological infrastructure of the business such as computers, operating systems and networks,' (Schekkerman, 2004a:13).

In short, 'enterprise architecture is about understanding all the different elements that go to make up the enterprise and how those elements interrelate,' (Schekkerman, 2005:4).

\section{Why the interest in Enterprise Architecture?}

A number of factors have helped to stimulate a growing interest in the field of EA in recent years: business imperatives, legislation, and a focus on corporate and IT governance.

King (1995), proposed a strategic capabilities architecture, and suggested that the guiding architecture of firms should be based on their strategic vision, a key business imperative, a view supported by Cecere (1998) and Schneider (1998). In addition, 'CIOs are re-embracing the corporate standardised platforms and applications that compose enterprise architecture as a way to contain costs and ensure business alignment,' (Mayor, 2001). In a similar vein, the main role of EA is considered the alignment of business processes and the supporting IT infrastructure to the business goals, which in turn improves corporate agility (Chorafas, 2002). 'Integrating enterprise architecture into the business is an issue facing many enterprises. To ensure IT capabilities in tune with business needs, enterprises need a new method of synchronising enterprise architecture with the business' Drobik (2002:1), where a good architecture provides the ability to support migration from the current state of the business to the desired future state (McGovern, Ambler, Stevens, Linn, Sharan \& Jo, 2004). In similar vein, Hagan (2004:17) stated that: 'Developing and using an enterprise architecture is directed at improving the management, planning, investment, and technology capabilities of an enterprise.' More recently, it has been noted that an interest in EA exists as it provides 'A coherent set of models, principles, guidelines, and policies, used for the translation, alignment, and evolution of the systems that exist within the scope and context of an Enterprise,' (GEAO, 2006).

The second major reason for an interest in EA is that of a legislative requirement, certainly in the United States of America (USA). The influence of the Clinger-Cohen Act (CCA) of 1996 has been well-noted (CIOC, 1999, 2001; Hagan, 2004; Schekkerman, 2004a), and the impact of the CCA in terms of US government agencies at all levels is widespread. The 1996 Clinger Cohen Act requires agencies to have an information technology architecture which 'with respect to an executive agency, means an integrated framework for evolving or maintaining information technology and acquiring new information technology to achieve the agency's strategic goals and information resources management goals,' (Hagan, 2004:13). The situation in other global regions is not yet as advanced in 
terms of legislation but there have been a number of initiatives, particularly in Europe, which have further stimulated interest in EA (Bernus et al., 2003).

The third major stimulus to EA interest lies in the area of governance, a subject that has received much attention in recent, post-Enron, years and has been identified by several authors (Cullen \& Leganza, 2006; ITGI, 2006; OMB, 2006; Schekkerman, 2005; The Open Group, 2006). Of these, one of the most influential factors is the Control Objectives for Information and related Technology (CobiT), a widely adopted framework for IT governance, which in its latest edition (Version 4.0) emphasises the role the Chief Architect has to play in an effective governance framework.

\section{Enterprise architecture frameworks evolution}

Although Zachman (Sowa \& Zachman, 1992; Zachman, 1987, 1996a, 1996b) can justifiably lay claim to be the originator of the field of EA, he is now by no means alone in proposing a framework for EA. As mentioned earlier, Spewak (1992) made a significant early contribution with EAP, and there have since emerged a number of alternative frameworks for EA. Some of these are in the public domain, some have been developed for use in specific environments and others originate as proprietary, branded solutions. A number of useful reviews of the variety of EA frameworks, which exist, have been published (Bernus, et al., 2003; Du Preez, 2003; Hagan, 2004; Martin \& Robertson, 2003; Schekkerman, 2004a; Tang et al., 2004; The Open Group, 2002; Williams \& Li, 1998).

The Open Group (2002) provided one of the most comprehensive reviews, and stated 'TOGAF [The Open Group Architecture Framework] is one of a number of architectures and architectural frameworks in use today. Many of the other architectural initiatives have a good deal in common with TOGAF.' Their list of EA frameworks indicated:

- C4ISR: Command, Control, Computers, Communications (C4), Intelligence, Surveillance, and Reconnaissance (ISR). Successor to TAFIM, launched in 1997 (see definition in this list) from the US Department of Defense (CIOC, 2001)

- $\quad$ EAP: Enterprise Architecture Planning (Spewak, 1992)

- Federal Enterprise Architecture (CIOC, 2001; OMB, 2006)

- FEAF: Federal Enterprise Architecture Framework (CIOC, 1999)

- ISO/IEC 14252 (IEEE 1003.0) (a forerunner to TAFIM)

- $\quad$ ISO 10746-4 Reference Model for Opened Distributed Processing (RM-ODP)

- $\quad$ SPIRIT (Service Providers Integrated Requirements for Information Technology) Platform Blueprint (published by The Open Group)
- TAFIM (US Department of Defense Technical Architecture Framework for Information Management, based on IEEE 1003.0). Used as a basis for TOGAF Version 1.0. Withdrawn in 2000.

- $\quad$ TEAF: Treasury Enterprise Architecture Framework from the US Department of the Treasury, launched in 2000 (CIOC, 2001).

- Zachman Framework for Enterprise Architecture (Zachman, 1996a)

There have been some additional developments in EA frameworks since 2002 (see Hagan, 2004; Martin \& Robertson, 2003; Schekkerman, 2004a; Tang et al., 2004) and most recently the Zachman Framework itself was revised in 2005 and is now called the Zachman Classification Framework for an Enterprise.

As part of the introduction and evolution of EA frameworks, a number of new commercial organisations, industry interest groups and associations have been formed. These include, amongst others, the Enterprise Architecture Interest Group (EAIG, 2006); the Global Enterprise Architecture Organisation (GEAO, 2006); the Institute for Enterprise Architecture Developments (which has developed the Extended Enterprise Architecture Maturity Model) (IFEAD, 2004); the International Enterprise Architecture Center (IEAC, 2006); and The Open Group (2006). Of these, IFEAD has been most active in the past three years in terms of conducting a survey of trends in EA (Schekkerman, 2004b, 2005), and it was the IFEAD 2004 survey which provided the background for this research project.

\section{Motivation}

Due to the duration and cost implications of EA projects, questions need to be answered on where there were successful outcomes and what contributed to the success. The belief is that the South African context differs from the contexts in existing studies in that SA is a developing country where all companies are going through a transformation period (especially the IT departments). Most of research available has an international focus (USA and Europe) (Chorafas, 2002; Schekkerman, 2004b). A situational analysis of EA implementation in SA was considered helpful in identifying such success factors specific to the South African context. These findings were also compared to the international findings as reported by Schekkerman (2005) to further enhance understanding of the local context. The focus of the research was on financial sectors since these sectors are dependent on IT and have therefore all started EA initiatives.

\section{Research problem}

In order to get an overview of EA practices in SA and to compare them to the international situation, the following question was asked: How do South African companies implement Enterprise Architecture in the financial sector?

The main research question was divided into sub-questions, which were addressed in a questionnaire. The sub-questions 
are divided into five different sections: the role of EA, the place of EA in organisational governance, the architects, practices and processes and the evaluation of EA efforts. The sub-questions are now discussed according to these categories:

The role of EA:

- Are companies aware of the growing importance of EA?

- $\quad$ For what kind of issues are EA projects often planned?

The place of EA in organisational and strategic governance:

- Which architectures are established within organisations?

- At which level does EA governance form a part of the organisational governance structure?

- At which level of the organisation is the EA initiative sponsored?

- $\quad$ Are EA initiatives organised as part of other projects or, is the focus exclusively on EA?

- To whom are the architects reporting within the organisation?

The architects:

- What are considered important characteristics of an enterprise architect?

- Do organisations have their own architects and what type of architects do they have?

- How many architects do companies have and what is the ethnographic profile of the architects?

- $\quad$ Are external architects used and if so, from which external organisations are they hired?

- How are the architects trained or educated?

- Is certification of enterprise architects considered important by companies?

- Are personnel sometimes coached by experienced architects and how often?

- What are the criteria for a good coach or mentor?

Practices and processes:

- Which EA frameworks are used or used as basis for own framework?

- What kind of EA tools is used?

- Which business modelling tools are used?
- Which application modelling techniques are used?

- Which system development methodologies are used?

Evaluating the EA project:

- Which issues are considered critical success factors (CSFs) for EA governance?

- Which elements are considered important in measuring the maturity of EA management?

- Which metrics are used or are planned to be used in measuring the success of an EA initiative?

\section{Research design}

A literature study was conducted to investigate practices and success factors of EA implementation. As was already mentioned, these mainly reported on international studies. Frameworks and results from these studies were used to design a questionnaire, which was distributed amongst EA practitioners in SA early in 2005. The focus of this study was on the JSE-listed financial sector (which itself is a small population compared to the equivalent populations in the USA and Europe) and six of the twelve practitioners that were initially approached completed the questionnaire. Although this is a small sample size it was felt to be worth investigating, since not only could it provide some indication of the current status of EA in the South African financial sector, but could also give an idea of how viable such a study is in the broader South African context if the scope were to be extended in future research. It was recognised that the results of such a small sample may neither be easily generalised across different business sectors in SA, nor outside the South African national context.

The questionnaire was largely based on an existing on-line survey used by the Institute For Enterprise Architecture Developments (IFEAD) (Schekkerman, 2004b), where the results were also compared to a later IFEAD survey (Schekkerman, 2005). Additional questions were derived from research done by Leganza (2003), Paras (2003) and The Open Group (2006). The questionnaire consisted of thirty-one questions of which the first five dealt with demographics. There were no open-ended questions and all questions gave several options from which the practitioner had to choose one (or more) options.

\section{Findings}

This section discusses the classification data gathered from the completed questionnaires. The first part of the questionnaire gave a background on the respondents.

\section{General information}

The first few questions of the questionnaire dealt with the categories of the organisations who participated in this research as well as the size of their IT departments. 
Table 1: Participants in this research

\begin{tabular}{l|l|l}
\hline $\begin{array}{c}\text { Number of } \\
\text { companies }\end{array}$ & $\begin{array}{c}\text { Number of people } \\
\text { working in the } \\
\text { organisation }\end{array}$ & $\begin{array}{c}\text { Size of IT } \\
\text { department }\end{array}$ \\
\hline 1 & 50000 or more & 1000 or more \\
\hline 1 & $25000-49999$ & 1000 or more \\
\hline 1 & $25000-49999$ & $500-999$ \\
\hline 2 & $10000-24999$ & $500-999$ \\
\hline 1 & $100-1000$ & $10-999$ \\
\hline
\end{tabular}

Five of the six companies were very large with one company having over 50000 people working in the organisation and an IT department of more than 1000 people. However, it seems as if not only large organisations adopt EA as a strategic governance tool but also smaller companies. The participants described themselves in various ways: two Enterprise Architects, one Chief Technology Officer, one Chief Group IT Architect, one Group Information architect, one Chief Enterprise Design Architect in Group Enterprise Architect.

\section{The role of enterprise architecture}

This section consisted of questions focusing on the role of EA and reasons for EA. Figure 1 shows the views of respondents on the reasons for planning EA.

The response to this question supported literature findings (Chorafas, 2002; Drobik, 2002) by showing that most respondents considered EA as a support for business and IT alignment as well as guiding change on several levels. These include renewal of applications and infrastructure, legacy transformation, business change as well as mergers or acquisitions. Changes and transformation on all levels of the organisation are becoming imperative because of the growing uncertainty in the global business environment. EA is therefore growing in importance since it is seen as a tool to manage these changes. All six companies indicated their awareness of the growing importance of EA.

\section{The place of EA in organisational and strategic governance}

This section of the questionnaire focused on EA governance and its place within the organisation. The Open Group

(2006) considers one of the key success factors for

successful EA governance the establishment of a crossorganisational Architecture Board with the backing of top management to coordinate the implementation and governance of EA. The level of executive management involvement, as well as the extent of enterprise involvement are in fact seen as measurements of the maturity of EA management within companies. The necessary implication of enterprise-wide and top management involvement in EA initiatives is that decision making about technical issues is often moved from the IT department to business executives. Figure 2 shows the respondents' views on this issue.

A follow up question tried to determine the level of the organisation at which the EA initiative is sponsored. All respondents indicated that the level where EA governance form part of the organisational governance structure is also the level where the EA initiative is sponsored. One company indicated that this happens at the director level (non-board). Figure 3 shows that although EA initiatives generally have the backing of top management and that EA governance forms part or strategic governance, the EA responsibilities are carried by the $\mathrm{CIO}$ and CTO and is not the responsibility of the CEO or business managers. This indicates a general lower maturity index profile of EA governance in the companies investigated. This observation is confirmed by the fact that four (4) of the six companies indicated that their EA initiatives are part of other projects and that the focus is not exclusively on EA.

\section{The architects}

The questions in this section dealt with the characteristics of architects, the type of architects in the companies and their training and education. Enterprise Architecture gives a picture of different sub-architectures of the organisation: the business architecture, the application architecture, the information and data architecture and the technology architecture (Du Preez, 2003; EWITA, 2002; Koch, 2005; Pelz-Sharpe \& Harris-Jones, 2005; Spewak, 1992). This makes the ideal enterprise architect a person with quite unique and broad skills. The Open Group considers business knowledge and knowledge of the prevailing business issues faced by the organization as imperative for enterprise architects. The table below shows the ranking by the respondents of other qualities considered important for enterprise architects to have.

\section{Table 2: Characteristics of enterprise architects}

\begin{tabular}{l|c}
\hline \multicolumn{1}{c|}{ Characteristics } & $\begin{array}{c}\text { Number of } \\
\text { companies who } \\
\text { agree }\end{array}$ \\
\hline $\begin{array}{l}\text { Having communication, negotiation } \\
\text { and relationship skills }\end{array}$ & 5 \\
\hline $\begin{array}{l}\text { Skilled and experienced in } \\
\text { producing designs }\end{array}$ & 4 \\
\hline Having problem solving skills & 4 \\
\hline $\begin{array}{l}\text { Having extensive technical breadth } \\
\text { with technical depth in one or a few } \\
\text { disciplines }\end{array}$ & 3 \\
\hline $\begin{array}{l}\text { Having a method-driven approach to } \\
\text { execution }\end{array}$ & 2 \\
\hline Having full project scope experience & 2 \\
\hline Showing leadership & 2 \\
\hline $\begin{array}{l}\text { Skilled and experienced in one or } \\
\text { more industries }\end{array}$ & 2 \\
\hline
\end{tabular}

Most organisations already have the technology and applications architecture in place. However, it is the presence and importance of the business and information architectural layers that indicate the maturity of the enterprise architecture initiatives in the organisation. Figure 4 depicts the scenario with respect to sub-architectures and the type of architects employed in the six companies. 
From Figure 4 it seems as if companies are in the process of shifting their focus to an enterprise wide architecture from a technology and application focused one.

Figures 5 and 6 depict the ethnographic distribution of the architects as well as the number of architects employed by the companies. Only four of the six companies answered this question. These figures give the averages of the number of architects over all four companies. Fifty-seven (57) architects work in the four companies.

Figure 6 confirms the observation that most companies who participated in this study are still in the process of broadening their architectural initiatives to the company as a whole.

It was already mentioned that enterprise architects need special and broad skills. Enterprise architects are often specialised in a sub-architecture by training (especially technology or applications architecture). Through selfeducation or in-house training these architects eventually end up in the position of designing enterprise-wide architectures. The following figure gives an indication of the training and education of the enterprise architects of the six companies.

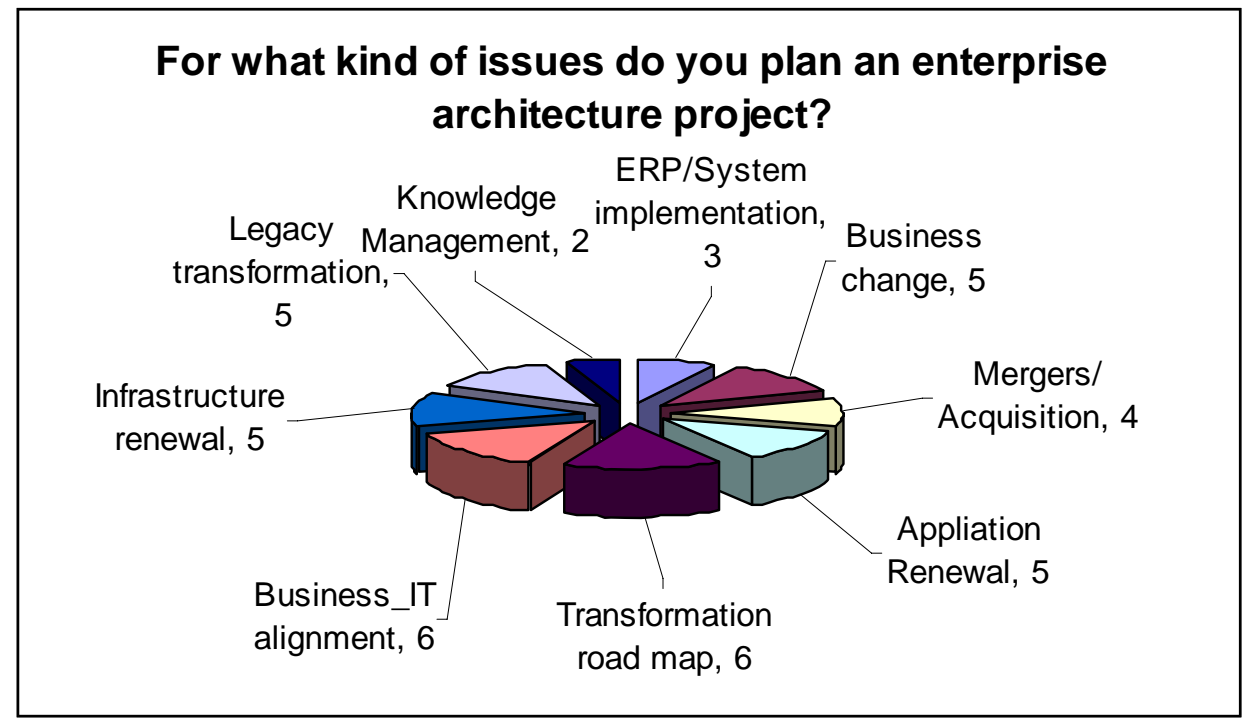

Figure 1: The role of enterprise architecture

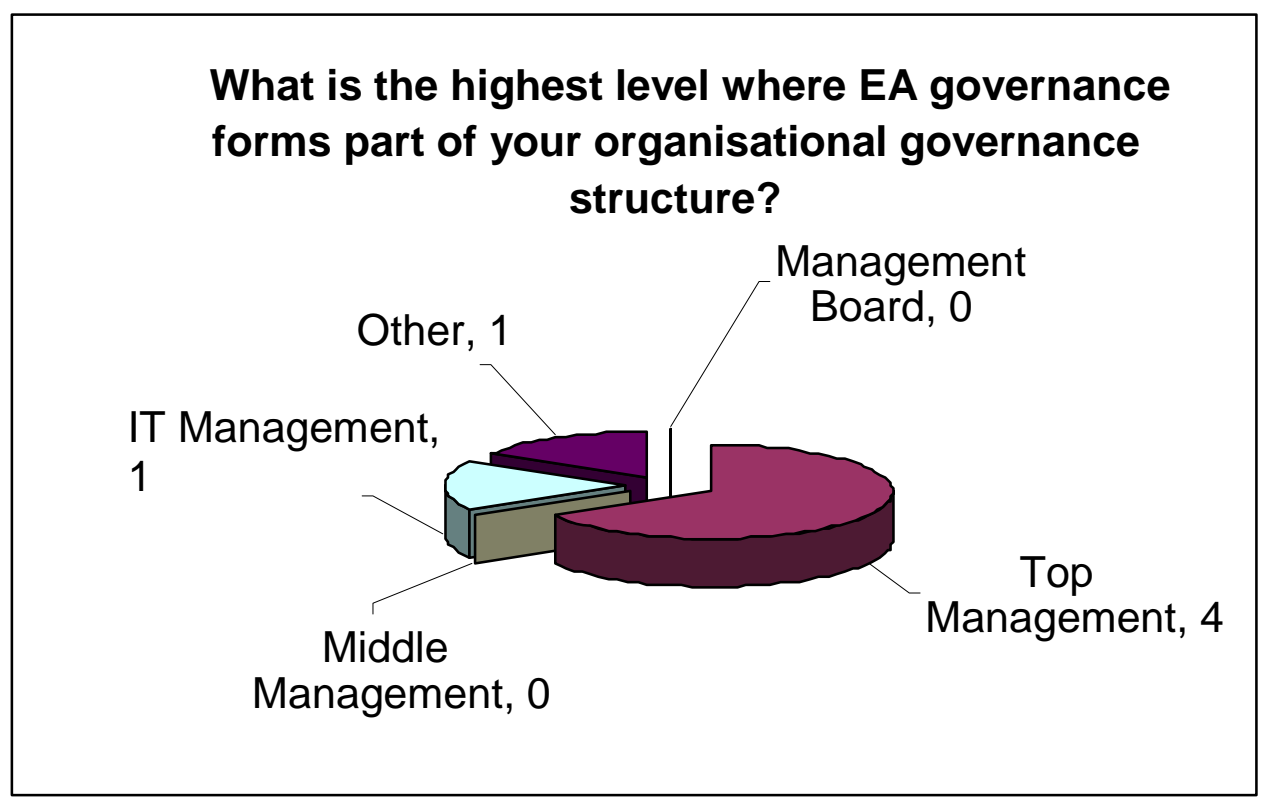

Figure 2: Place of enterprise architecture governance 


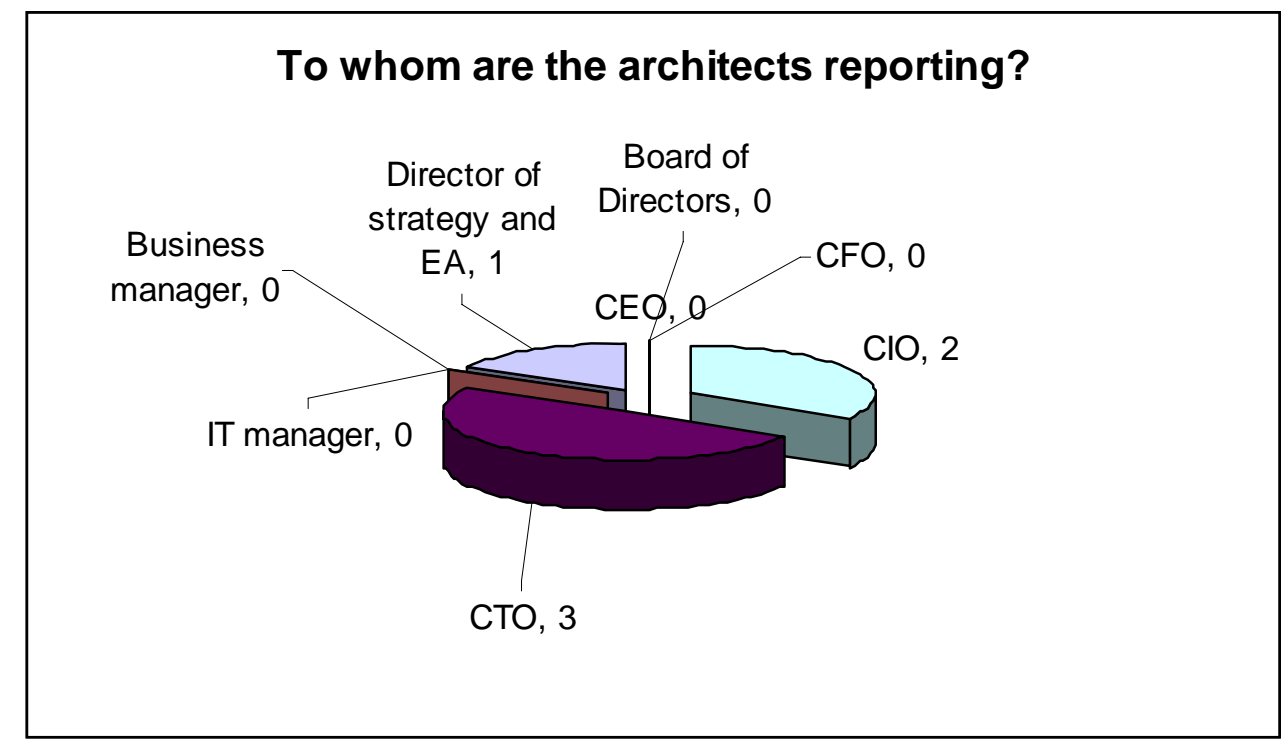

Figure 3: Reporting structure of architects

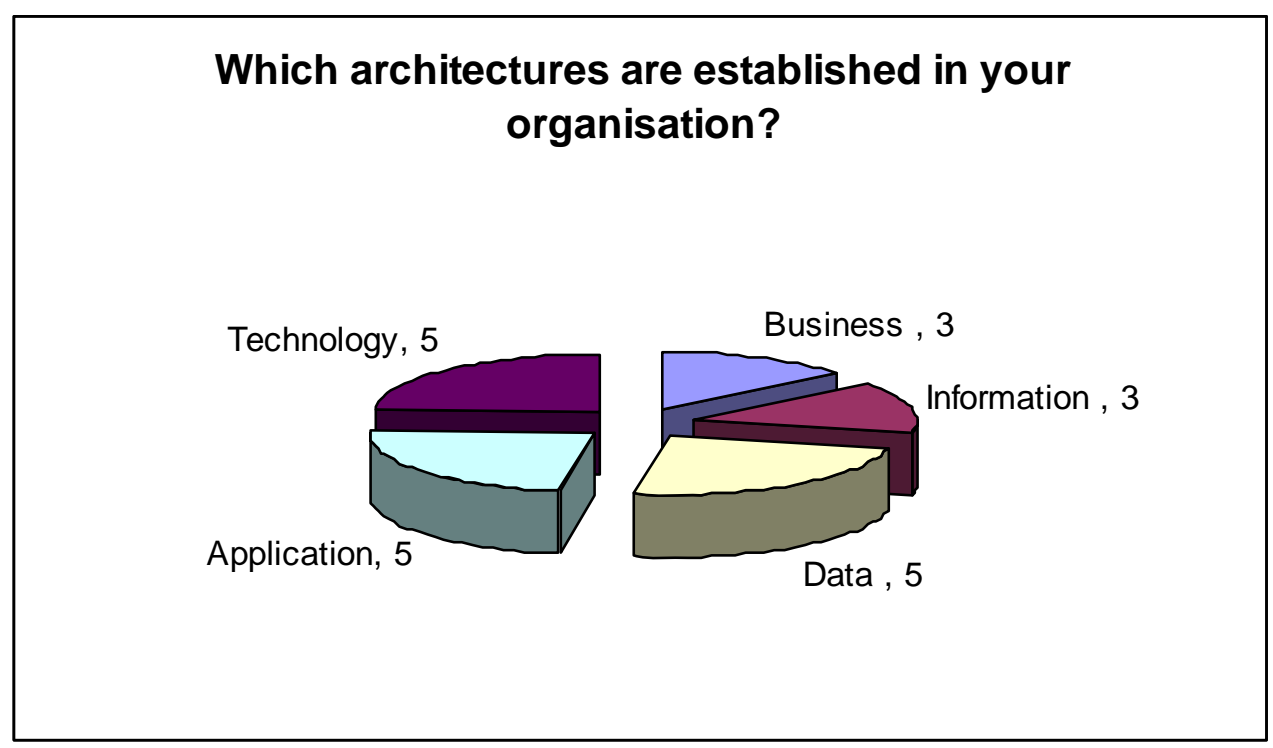

Figure 4: Established architectures

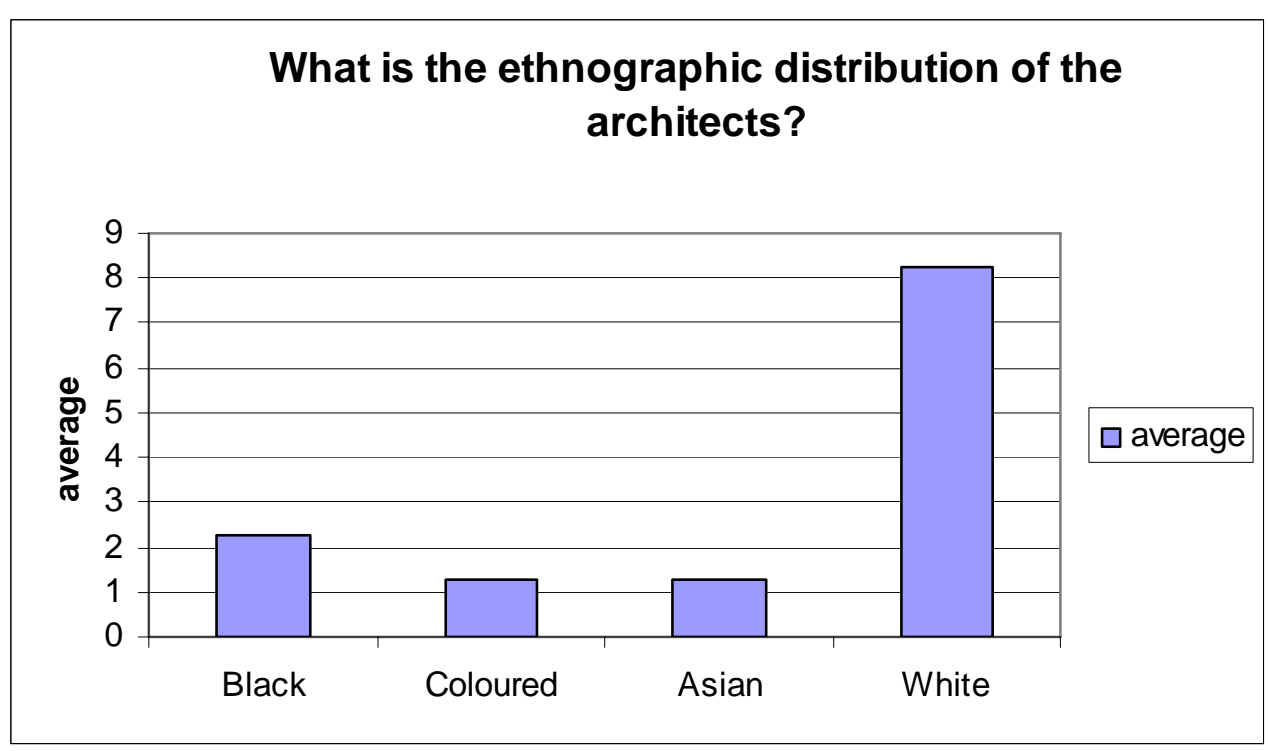

Figure 5: Ethnographic distribution of architects 


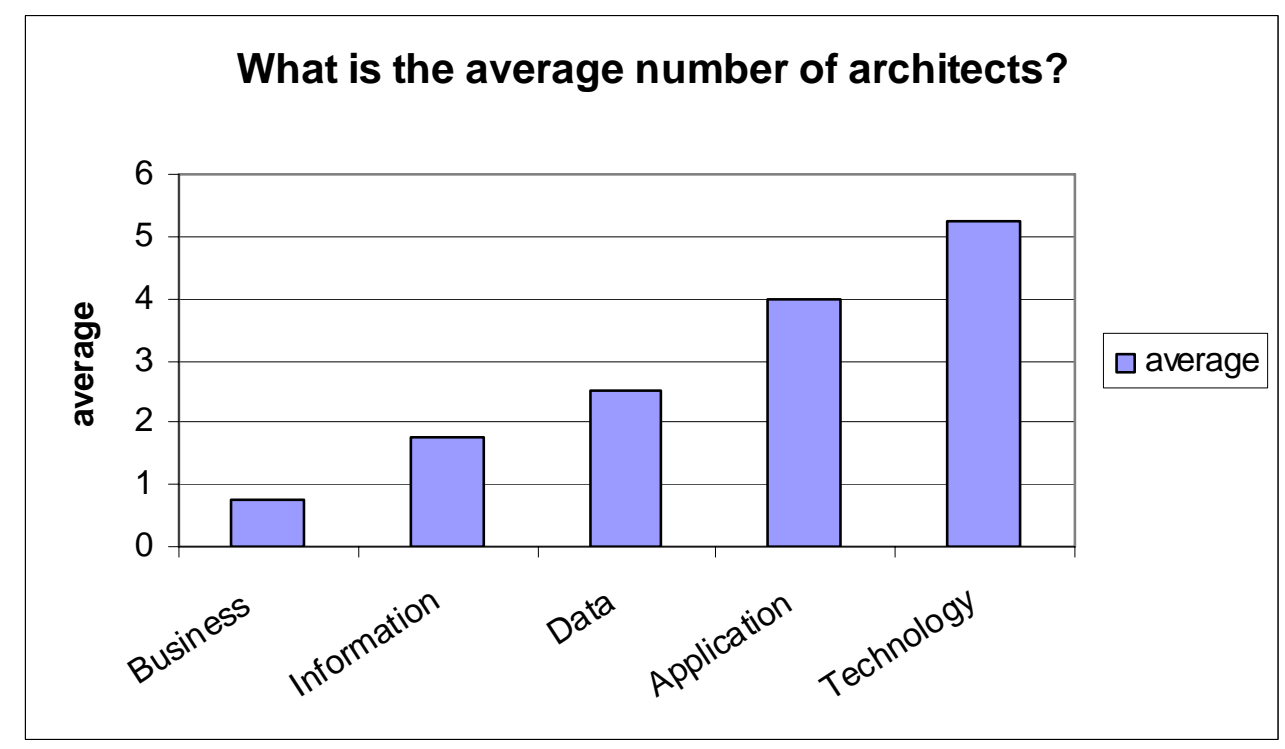

Figure 6: Average number of architects in companies

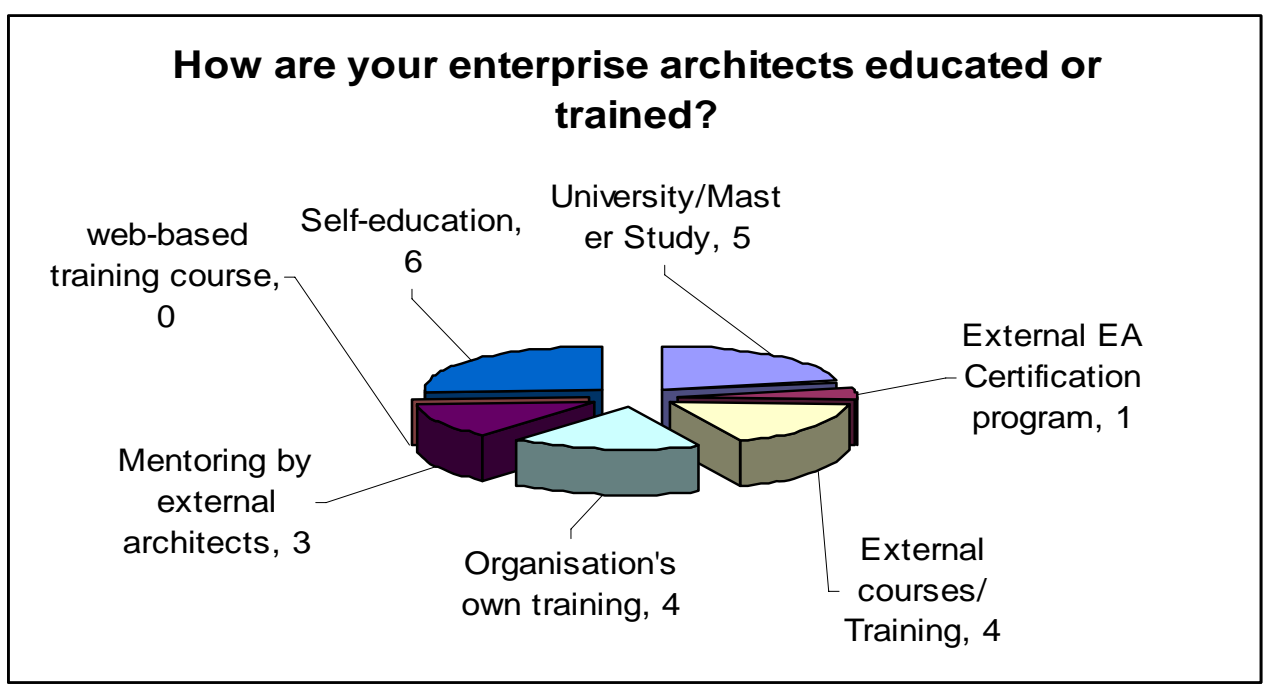

Figure 7: Enterprise architects' training

Although all companies indicated that they have their own architects, all participants indicated that they use external architects. This external support is mostly hired from smaller EA consulting companies (4 out of 6) or are independent consultants (4 out of 6).

At least half of the companies (3 out of 6) organize coaching by experienced EA for their architects. All six participants consider proven experience as the basis for choosing such a coach or mentor. Other factors that they consider (4 out of 6 ) are the reputation of the person as well as the knowledge of that person about methods, frameworks and approached. Relevant publications published by such a person seem to play a smaller role (2 out of 6). Certification of enterprise architects, by an official authority, is considered unimportant by the participants. Only one company indicated that such certification should be required.

\section{Practices and processes}

This section consisted of questions determining the popular EA frameworks, tools, techniques and methodologies. EA frameworks are considered important and helpful since it provides a classification system that includes all elements and perspectives of the organisations that should be considered in designing the EA blueprint. Figure 8 indicates the frameworks that are currently in use in five of the six companies. One company indicated that no such framework exists at this stage since EA is still in infancy stage.

On the question about the use of enterprise architecture tools, four of the five companies indicated that they use Microsoft Visio as enterprise architecture tool. Other tools that were mentioned include Borland TogetherJ (1), ARCHI (1), Casewise Modeler (1), IDS Scheer 'Aris Process Platform' (2) and Rational, Web Intermediaries (WBI) together with MetaGroup and Rochade (1). 


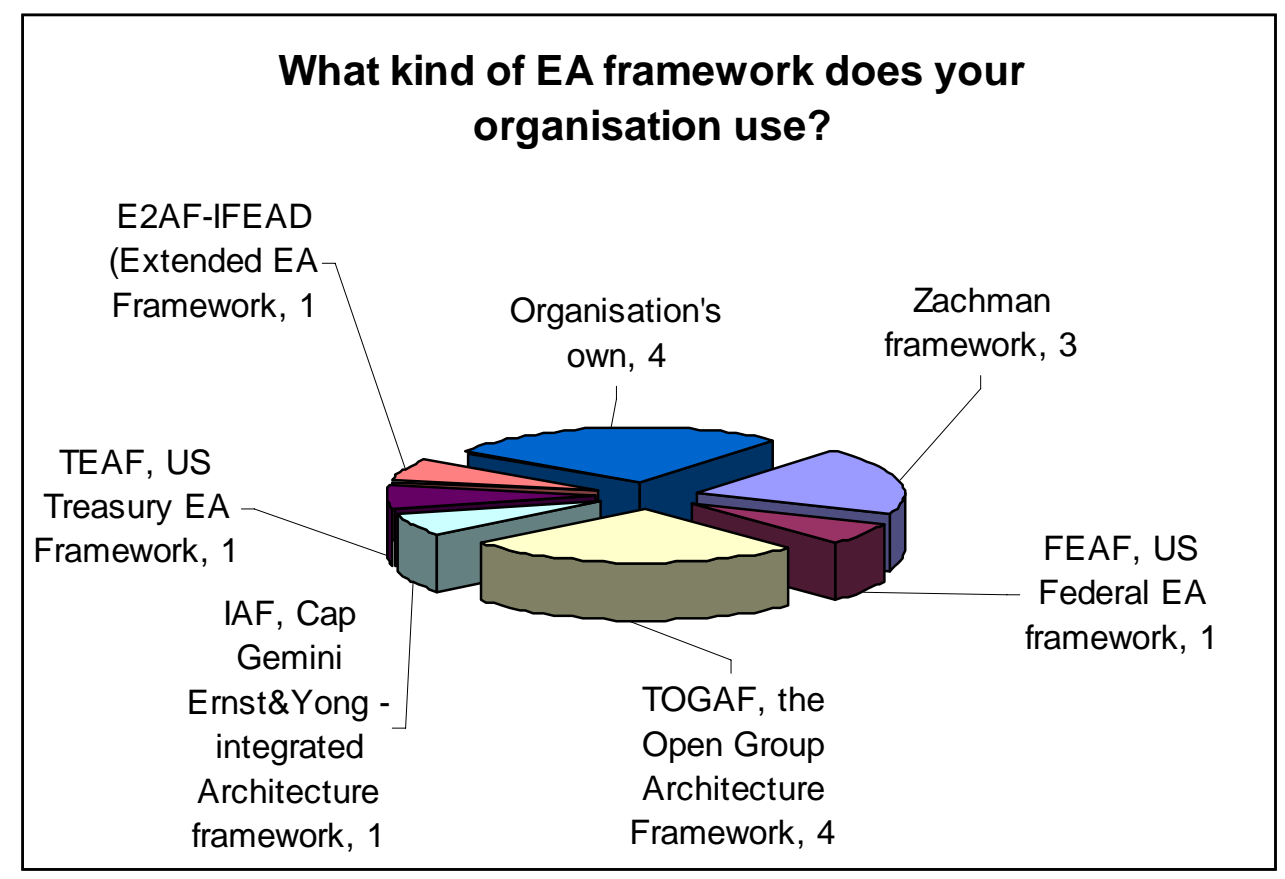

Figure 8: Enterprise architecture frameworks in use

Business Process Modelling (4) and IDEF (Integration Definition for Functions modelling techniques) (3) were considered popular business modelling techniques. However, most companies (4 out of 6) indicated that they use their own business modelling tools.

Unified Modelling Language (UML) (6 out of 6) and objectoriented techniques (5 out of 6 ) were considered the most popular application modelling techniques. Functional decomposition (4), flow charts (3) and Interface Definition Language (1) are also used. At least half of the participants use their own application modelling techniques.

The system development methodology that is most popular is the waterfall method (5 out of 6) whereas Rapid Application Development (RAD) (4 out of 6) is also considered useful. Rational Unified Process (RUP) (3 out of 6 ), Xtreme programming (2 out of 6) and Iterative Application Development (IAD) (2 out of 6) are also applied in the companies.

\section{Evaluating the enterprise architecture project}

It seems to be a generally accepted fact that EA adds value to an organisation (Chorafas, 2002; Drobik, 2002; Hagan, 2004; Schekkerman, 2004a). However, the measurement of this added value in financial terms is still hard to do (Schekkerman, 2004b). The last section of the questionnaire tried to deal with this difficult matter. There are some factors that could act as metrics in the measurement of the success of the EA initiative on other aspects than the financial gain. Ideas from Paras (2003) were used to derive some metrics, which were subsequently used in the questionnaire to test the participants view on the perceived validity of these metrics. Only five out of the six companies answered this question. The sixth company indicated that since EA is still in infancy stage no such metrics are in place or envisaged to be in place in the near future. Tables 3, 4 and 5 summarise the responses.

Although it is difficult to measure the success of EA initiatives, there are a few factors that could be kept in mind to ensure success (The Open Group, 2006). Participants indicated (see Table 4) which factors they deem the most important in ensuring success.

One company indicated that the overall IT process maturity of the organisation should also be considered a CSF.

It became clear from the responses received that not all of the companies that participated in this research are on the same maturity level regarding the EA management and implementation. There are several elements that could be considered in establishing the maturity of the EA management in a company. Table 5 summarises the participants' views on which elements should be considered in determining the maturity level of EA implementation in a company (IFEAD, 2004). 
Table 3: Metrics for enterprise architecture implementation

\begin{tabular}{l|c}
\hline \multicolumn{1}{c|}{ Metrics } & $\begin{array}{c}\text { Number of } \\
\text { companies } \\
\text { who agree }\end{array}$ \\
\hline $\begin{array}{l}\text { Percentage of IT projects undergoing architecture } \\
\text { review against plan }\end{array}$ & 5 \\
\hline $\begin{array}{l}\text { Number of new project initiatives recommended } \\
\text { from EA that are accepted }\end{array}$ & 4 \\
\hline $\begin{array}{l}\text { Percentage of EA model recommendations } \\
\text { approved by governance committees }\end{array}$ & 4 \\
\hline $\begin{array}{l}\text { Percentage of desired EA models that have been } \\
\text { completed }\end{array}$ & 3 \\
\hline $\begin{array}{l}\text { Percentage of projects receiving EA coaching or } \\
\text { consulting }\end{array}$ & 3 \\
\hline $\begin{array}{l}\text { Percentage of business and IT staff actively } \\
\text { participating in architecture process }\end{array}$ & 3 \\
\hline $\begin{array}{l}\text { Percentage of IT projects getting formal or } \\
\text { informal variance from architecture standards }\end{array}$ & 3 \\
\hline $\begin{array}{l}\text { Percentage of variances resolved by redesign to } \\
\text { become compliant }\end{array}$ & 3 \\
\hline $\begin{array}{l}\text { Degree of component reuse } \\
\text { Percentage of favourable business sponsor }\end{array}$ & 3 \\
\hline
\end{tabular}

Table 4: Critical success factors for enterprise architecture

\begin{tabular}{l|c}
\hline \multicolumn{1}{c|}{ Critical success factors } & $\begin{array}{c}\text { Number of } \\
\text { companies who } \\
\text { agree }\end{array}$ \\
\hline $\begin{array}{l}\text { The establishment of a comprehensive set } \\
\text { of architectural principles to guide, inform } \\
\text { and support the way in which an } \\
\text { organisation sets about fulfilling its mission } \\
\text { through the use of IT }\end{array}$ & 6 \\
\hline $\begin{array}{l}\text { The adoption of an architecture compliance } \\
\text { strategy which entails specific measures to } \\
\text { ensure compliance with the architecture, } \\
\text { including project impact assessment and a } \\
\text { formal architecture compliance review } \\
\text { process. }\end{array}$ \\
\hline $\begin{array}{l}\text { The establishment of a cross-organisational } \\
\text { Architecture Board with the backing of top } \\
\text { management to oversee the implementation } \\
\text { of EA and the governance thereof. }\end{array}$ \\
\hline $\begin{array}{l}\text { The management of the criteria for the } \\
\text { control of the architecture governance } \\
\text { processes, dispensations, service level } \\
\text { agreements and operational level } \\
\text { agreements. }\end{array}$ \\
\hline $\begin{array}{l}\text { The integration of tools and processes to } \\
\text { facilitate take up of the EA processes both } \\
\text { procedurally and culturally. }\end{array}$ \\
\hline $\begin{array}{l}\text { Meeting the internal and external } \\
\text { requirements for the effectiveness, } \\
\text { efficiency, confidentiality, integrity, } \\
\text { availability, compliance and reliability of } \\
\text { all architecture governance related } \\
\text { information, services and processes }\end{array}$ \\
\hline
\end{tabular}

Table 5: Maturity of enterprise architecture implementation

\begin{tabular}{l|c}
\hline \multicolumn{1}{c|}{ Elements } & $\begin{array}{c}\text { Number of } \\
\text { companies }\end{array}$ \\
\hline $\begin{array}{l}\text { Business and technology strategy } \\
\text { alignment }\end{array}$ & 6 \\
\hline Executive management involvement & 6 \\
\hline Extended enterprise involvement & 5 \\
\hline Business units involvement & 4 \\
\hline $\begin{array}{l}\text { Enterprise program management } \\
\text { (program or project management office } \\
\text { participates with EA program office in } \\
\text { the enterprise strategic planning process) }\end{array}$ & 4 \\
\hline $\begin{array}{l}\text { EA program office (establishment of EA } \\
\text { program and program office; } \\
\text { measurement of EA program activities } \\
\text { and results) }\end{array}$ & \\
\hline $\begin{array}{l}\text { Strategic governance (alignment of } \\
\text { governance with EA results) }\end{array}$ & \\
\hline $\begin{array}{l}\text { Enterprise budget and procurement } \\
\text { strategy (alignment of enterprise business } \\
\text { and IT budget and procurement } \\
\text { strategies) }\end{array}$ & 3 \\
\hline $\begin{array}{l}\text { EA developments (EA program office } \\
\text { manages projects portfolio and aligns } \\
\text { overall activities and initiatives) }\end{array}$ & \\
\hline $\begin{array}{l}\text { EA results (communication of EA results; } \\
\text { use of EA results in strategic planning) }\end{array}$ & 2 \\
\hline
\end{tabular}

\section{The South African situation}

When these findings are compared with the similar international studies conducted by Schekkerman (2004b, 2005) in 2004 as well as 2005, the following observations can be made. The current SA-based and international studies show that:

- $\quad$ EA is prominent in both large and small companies. The international studies show that the EA maturity level of smaller companies are usually lower than that of bigger companies. This tendency is not repeated in the current SA-based study as no small (non-JSE listed companies) were studied.

- The most important contribution of EA is considered the support of the management of complexity; transformation; and business and IT alignment. This tendency is repeated in the current SA-based study

- $\quad$ Most companies are aware of the growing importance of EA: EA is often the responsibility of the CIO and IT managers instead of the CEO and business managers. The international study conducted in 2005, shows a shift of responsibility for EA from the CIO to Board members and business managers. This tendency is not repeated in the current SA-based study

- The 2005 international study reflects a growth in the number of companies that have enterprise architects. This tendency is not repeated in the current SA-based study as most architects within companies in the current study are technology and application architects. 
- The 2005 international study indicates that most Enterprise Architects are self-educated and certification by an official authority is considered unimportant. However, in the current SA-based study, apart from self-education local enterprise architects are also trained by the organisation itself as well as by external architects.

- The international study of 2005 indicates that knowledge of methods and frameworks is deemed as important as proven experience. The international study also shows that some importance is attached to relevant publication by the expert. This is considered unimportant by the South African companies. Locally, proven experience is the preferred way of choosing such an expert.

- In the 2005 international study, most companies prefer to use their own EA frameworks, although there is reported a significant growth in the use of Zachman (from $13 \%$ to $25 \%$ ) and some increase in the use of TOGAF (an increase from $9 \%$ to $11 \%$ ). The local study shows a large preference for Zachman (3 out of 6) and TOGAF (4 out of 6) as opposed to EA frameworks developed by SA-based survey participants.

- The international studies (2004 and 2005) show a growth in the presence of Popkin's System Architect (since renamed Telelogic System Architect) tool. This tendency is not repeated in the current SA-based study, where Microsoft Visio is the most popular EA tool.

- The international studies (2004 and 2005) indicate UML is a popular system modelling technique rather than the use of similar in-house developed techniques. The local study indicates a heavier reliance on the company's own business and systems modelling techniques.

\section{Conclusion}

This study investigated a variety of aspects of EA in six South African companies from the JSE-listed financial services sector. It was found that EA is prominent in both large and small companies and that the EA maturity level of these companies differs but is not linked to their size. Most respondents considered the most important role of EA as support for business and IT alignment as well as guiding change on several levels.

Although all companies in this study were aware of the growing importance of EA, in most of these companies EA is still the responsibility of the CIO and IT managers instead of the CEO and business managers. This indicates a general lower maturity index profile of EA governance in the companies that were investigated.

Most of the architects in the companies are technology and application architects. The companies employ on average eight white, two black, one coloured and one Asian architect(s). Most of them are self-educated or have university training. Companies in general also provide training for their architects.

The TOGAF and Zachman frameworks seem to be the most popular frameworks in use and Microsoft Visio is the most popular EA tool. Business Process Modelling was indicated as a popular business modelling technique and UML as the most popular application modelling technique. However, there is also a heavy reliance on the business' own business and system modelling techniques. Five out of six companies indicated the waterfall method as the most useful system development methodology.

All respondents indicated that the establishment of $a$ comprehensive set of architectural principles to guide, inform and support the way in which an organisation fulfils its mission through the use of IT as well as the adoption of an architecture compliance strategy as the two most important critical success factors for EA. They all agreed that good indicators of the maturity level of EA implementation in a company are: a high level of business and technology strategy alignment and executive management involvement.

When comparing the South African study to the international studies (especially Schekkerman, 2005), the international respondents demonstrate a higher level of maturity with respect to EA implementation: the international study conducted in 2005, shows a shift of responsibility for EA from the CIO to Board members and business managers. This is not the case in SA. Also, the 2005 international study reflects a growth in the number of companies that have enterprise architects. In the SA study most architects were technology and application architects.

It is also interesting that although the local study showed a heavy reliance of companies on their own business and system modelling techniques, the Zachman and TOGAF frameworks are more widely used in the South African companies compared to the international companies.

The potential for generalisation of the findings of this study is acknowledged to be limited by the small sample of companies that were investigated. However, it is the view of the authors that the current study does yield valuable results and that by broadening the scope and content of this present study, a future study could add value to the practices of local EA practitioners by enabling them to understand their field better and position themselves both locally and internationally.

\section{References}

Bernus, P., Nemes, L. \& Schmidt, G. 2003. Handbook on the enterprise architecture. Berlin: Springer-Verlag.

Cecere, M. 1998. 'Architecting architecture'. [online] URL: http://www.cio.com/archive/041598/view.html . Accessed 12 April 2006.

CIOC (Chief Information Officer Council). 1999. 'Federal Enterprise Architecture Framework’. [online] URL: 
http://www.cio.gov/documents/fedarch1.pdf. Accessed 12 May 2006.

CIOC (Chief Information Officer Council). 2001. 'A practical guide to Federal Enterprise Architecture'. [online] URL: $\quad$ http://www.cio.gov/documents/bpeaguide.pdf. Accessed 12 April 2006.

Chorafas, D.N. 2002. Enterprise architecture and new generation information systems. Florida: CRC Press.

Cullen, A. \& Leganza, G. 2006. 'Topic overview: Enterprise architecture'. [online] URL: http://www.forrester.com/Research/Document/0,7211,39183 ,00.html. Accessed 12 April 2006.

Drobik, A. 2002. 'Enterprise architecture: The business issues and drivers'. [online] URL: http:// www.gartnerg2.com/research. Accessed 12 April 2006.

Du Preez, G. 2003. 'Enterprise architecture framework: Presentation to itSMF'. [online] URL: http:// www.itsmf.org.za/Presentations/Presentations2003/Enterpris e\%20 Architecture\%20Frameworks.pps. Accessed 12 April 2006.

EAIG (Enterprise Architecture Interest Group). 2006. 'Operating principles'. [online] URL: http:// www.eaig.org/aboutus principles htm. Accessed 21 May 2006.

EWITA (Enterprise Wide Information Technology Architecture). 2002. 'Enterprise architecture definition'. [online] URL: http://www.ewita.com/EA Overview/ EADefinition htm. Accessed 15 May 2006.

GAO (General Accounting Office). 2003. 'A Framework for assessing and improving enterprise architecture management'. [online] URL: http:// www.gao.gov/new.items/d03584g.pdf Accessed 19 May 2006.

GEAO (Global Enterprise Architecture Organisation). 2006. 'GEAO definition of enterprise architecture'. [online] URL: http://www.geao.org/ea definition htm. Accessed 12 April 2006.

Hagan, P. 2004. 'Enterprise architecture body of knowledge'. [online] URL: http://.www mitre.org/eabok. Accessed 12 April 2006.

Harrison, D. \& Varveris, L. 2004. 'TOGAF: Establishing itself as the definitive method for building enterprise architectures in the commercial world'. [online] URL: http://www.developer.com/design/article.php/3374171. Accessed 12 April 2006.

ITGI (Information Technology Governance Institute). 2006. 'CobiT 4.0'. [online] URL: http://www.itgi.org . Accessed 3 June 2006.
IEAC (International Enterprise Architecture Center). 2006a. 'About the International Enterprise Architecture Center'. [online]. URL:

http://www.ieac.org/Knowledge Library/index htm. Accessed 21 May 2006.

IEAC (International Enterprise Architecture Center). 2006b. 'Knowledge library'. [online]. URL: http:// www.ieac.org/Knowledge Library/index.htm. Accessed 21 May 2006.

IFEAD (Institute For Enterprise Architecture Developments), 2004. 'Extended Enterprise Architecture Maturity Model'. [online] URL: http:// www.enterprise-architecture.info. Accessed 10 October 2004.

King, W.R. 1995. 'Creating a strategic capabilities architecture’, Information Systems Management, 12(1):6769.

Koch, C. 2005. 'A new blueprint for the enterprise'. [online] URL: http://www.cio.com/archive/030105/blueprint.html. Accessed 12 April 2006.

Leganza, G. 2003. 'Project governance and enterprise architecture go hand in hand'. Giga Research. [online]. URL:

http:/www mega.com/en/company/industry perspective/pdf/ giga.governance.pdf. Accessed 12 April 2006.

Mayor, T. 2001. 'Back to the drawing board: architecture'. [online] URL:

http://www.cio.com/archive/080101/board html. Accessed 12 April 2006.

Martin, R. \& Robertson, E. 2003. 'A comparison of frameworks for enterprise architecture modelling'. [online] URL: http://www.tinwisle.com/modeling/MR ER2003.pdf Accessed 12 April 2006.

McGovern, J., Ambler, S.W., Stevens M.E., Linn, J., Sharan, V. \& Jo, E.K. 2004. A practical guide to enterprise architecture. New Jersey: Prentice Hall.

OMB (Office of Management and Budget). 2006. 'Federal enterprise architecture'. [online] URL: http:// www.whitehouse.gov/omb/egov/a-1-fea.html. Accessed 12 April 2006.

Paras, G. 2003. Three Dimensions of EA Process Metrics. Delta, 2670 [online] URL:

http://www metagroup.com/us/displayArticle.do?oid=45866 . Accessed 14 October 2004.

Pelz-Sharpe, A. \& Harris-Jones, C. 2005. 'Knowledge management - past and future’, KM World, 14(1):8-10.

Schekkerman, J. 2004a. How to survive in the jungle of Enterprise Architecture Frameworks. Victoria: Trafford. 
Schekkerman, J. 2004b. 'Trends in enterprise architecture'. [online] URL: http://www.enterprise-architecture.info. Accessed 10 October 2004.

Schekkerman, J. 2005. 'Trends in enterprise architecture'. [online] URL: http://www.enterprise-architecture.info. Accessed 2 May 2006.

Schneider, P. 1998. 'Blueprint for harmony'. [online] URL: http:/www.cio.com/archive/090199/acrimony.html. Accessed 12 April 2006.

Sowa, J.F. \& Zachman, J.A. 1992. 'Extending and formalizing the framework for information systems architecture', IBM Systems Journal, 31(3):590-617.

Spewak, S.H. 1992. Enterprise architecture planning, developing a blueprint for data, applications and technology. New York: John Wiley and Sons.

Tang, A., Han, J. \& Chen, P. 2004. 'A comparative analysis of architecture frameworks'. Proceedings of the $11^{\text {th }}$ AsiaPacific Software Engineering Conference. [online] URL: http://www.it.swin.edu.au/centres/cecses/trs/2004/SUT.CeC SES-TR001.pdf. Accessed 12 April 2006.

Tapscott, D. \& Caston, A. 1993. Paradigm shift: The new promise of information technology. New York: McGrawHill.

The Open Group. 2002. 'Other architectures and architectural frameworks'. [online] URL: http:// www.opengroup.org/architecture/togaf8-

doc/arch/p4/others/others.htm. Accessed 12 May 2006.

The Open Group. 2006. 'What is TOGAF?' [online] URL: http://www.opengroup.org. Accessed 12 May 2006.

Van der Klashorst, L. 2001. 'Nedcor technology and operations: Enterprise architecture (the knowledge-base)', South African Journal of Information Management, 3(4). [online] URL: http://www.sajim.co.za. Accessed 12 April 2006.

Williams, T.J. \& Li, H. 1998. 'PERA and GERAMenterprise reference architectures in enterprise integration'. [online] URL:

http://iies.www.ecn.purdue.edu/IIES/PLAIC/diism98.

Accessed 19 May 2006.

Zachman, J.A. 1987. 'A framework for information systems architecture’, IBM Systems Journal, 26(3):276-292.

Zachman, J.A. 1996a. 'Enterprise architecture: The issue of the century'. [online] URL: http://mega.ist.utl.pt/ icatsi/TheIssueOfTheCentury.pdf. Accessed 12 April 2006.

Zachman, J.A. 1996b. 'The framework for enterprise architecture: Background, description and utility'. [online] URL:

http://home hib no/AI/data/fag/D056 2003/Zachman\%5CZI FA\%20Description.pdf. Accessed 12 April 2006.
Zachman, J.A. 2006. 'The Zachman Framework'. [online] URL: http://www.zifa.com. Accessed 12 April 2006. 
